\title{
The Effect of Direct Oral Anticoagulant Drugs on Platelet Indiceses and Their Relationship with Bleeding Events
}

\section{Direkt Oral Antikoagülan Ilaçların Platelet Indekslerine Etkileri ve Bunun Kanama Olaylarıyla Ilişkisi}

Fatih Aydin ${ }^{1}$,

Ozge Turgay Yildirim ${ }^{1}$,

Ercan Aksit ${ }^{2}$,

Evrin Dagtekin ${ }^{1}$,

Ayse Huseyinoglu Aydin ${ }^{1}$

Eskişehir City Hospital, Department of Cardiology, Eskisehir, Turkey

${ }^{2}$ Canakkale Onsekiz Mart University,

Department of Cardiology, Canakkale, Turkey

Gelis Tarihi/Received: 2 December 2019

Kabul Tarihi/Accepted: 12 March 2020

Address correspondence to: Fatih Aydin, Eskişehir City Hospital, Department of Cardiology, Eskisehir, Turkey

e-mail: drfatihaydin@hotmail.com

\section{ORCID}

Fatih Aydin

https://orcid.org/0000-0002-1017-1917

Ozge Turgay Yildirim

https://orcid.org/0000-0002-6731-4958

Ercan Aksit

https://orcid.org/0000-0002-4478-4324

Evrin Dagtekin

https://orcid.org/0000-0002-6731-4958

Ayse Huseyinoglu Aydin

https://orcid.org/0000-0002-3056-9981

\begin{abstract}
Öz
Amaç: Atriyal fibrilasyon(AF) yaygın bir hastalıktır ve tromboembolilerin önemli bir nedendir. Son zamanlarda, doğrudan oral antikoagülan ilaçlar (DOAK'lar)bu hastalar arasında tromboembolik olayların sıklığını azaltmak için kullanılmaktadır. DOAK'ların sabit doz kullanımı ve daha az yan etki gibi oral K vitamini antagonistlerine karşı bir takım avantajları vardır. Ancak, etkileri doğrudan izlenemediği için bu ilaçların etkinlikleri ve yan etkileri değerlendirilemektedir. Bu çalışmada trombosit indekslerinin DOAK'lar üzerinde etkisi incelenerek bunların tromboembolik ve hemorajik olaylarla ilişkisi araştırıldı.

Hastalar ve Yöntem: DOAK kullanan 301 atriyal fibrilasyon hastası çalışmaya dahil edilmiştir. Birinci ve altıncı aylarda trombosit sayısı, trombosit dağılım hacmi,trombosit, trombosit-büyük hücre oranı değerlendirildi. DOAK'ların bu indeksler üzerindeki etkisi ve kanama olayları ile ilişkileri araştırıldı.

Bulgular: Rivaroksaban kullanan grupta P-LCR daha düşük saptanması dışında tüm grupların başlangıç trombosit indeksleri açısından fark yoktu. Tedavi sonrası sonuçlar karşılaştırıldığında grupların tüm parametrelerde benzer değerlere sahip olduğu bulundu. Ancak, zamana bağlı karşılaştırmalarda apiksaban ve dabigatran gruplarında 6.ayın sonunda P-LCR değerinin anlamlı ölçüde azalttığı gözlendi.

Sonuç: Bu çalışma valvüler olmayan AF hastalarının tam kan sayımında apiksaban, rivoraksaban ve dabigatran kullanımının trombosit sayısı, MPV, PDW ve PCT değerleri üzerinde hiçbir etkisinin olmadığını
\end{abstract} gösterdi.

Anahtar Kelimeler: Trombosit indeksleri, direkt oral antikoagülan ilaçlar, atriyal fibrilasyon

\section{Abstract}

Aim: Atrial fibrillation is a common disorder and is an important cause of thromboembolic events. Recently, direct oral anticoagulant drugs (DOACs) are being used to reduce the frequency of thromboembolic events among these patients. DOACs have several advantages over oral vitamin $\mathrm{K}$ antagonists, such as fixed dosage and fewer side effects. However, since the drugs and their affects cannot be monitored directly, difficulties are encountered in assessing drug efficacy and side effects. For this purpose, platelet indices and their relationship with DOACs may be utilized for the prediction of thromboembolic and hemorrhagic events.

Patients and Methods: 301 patients with atrial fibrillation who were using DOACs were included in the study. Platelet indices such as platelet count, platelet distribution volume, plateletcrit, platelet-large cell ratio were evaluated at the first and sixth months. The effect of DOACs on these indices and relationships with bleeding events were investigated.

Results: All groups were similar in regard to baseline platelet indices, except for lower P-LCR value among recipients of rivaroxaban. When post-treatment results were compared, all groups were found to have similar values in all parameters. However, time-bound comparisons revealed that apixaban and dabigatran significantly reduced P-LCR value after 6 months of use.

Conclusion: This study showed that apixaban, rivoraxaban and dabigatran had no effect on platelet count, MPV, PDW, PCT values in whole blood count of patients with non-valvular AF. All characteristics of those with and without hemorrhagic events were also similar of patients with non-valvular AF.

Key words: Platelet indices, direct oral anticoagulant drugs, atrial fibrillation

\section{INTRODUCTION}

Atrial fibrillation (AF) is a common cardiac arrhythmia which increases the risk of thromboembolic events and mortality $(1,2)$. In order to reduce the risk of stroke and thromboembolism, anticoagulant therapy is currently being used in AF patients with a
CHADSVASc score higher than 1 (3). Anticoagulant therapy was limited to vitamin $\mathrm{K}$ antagonists (warfarin) until 2009; afterwards, a new treatment option emerged with the approval of direct oral anticoagulants (DOACs) (4). Today, DOACs are a staple of AF management due to good clinical outcomes
Cite this article as: Aydin F, Yildirim OT, Aksit E, Dagtekin E, Aydin AH. The Effect Of Direct Oral Anticoagulant Drugs On Platelet Indiceses And Their Relationship With Bleeding Events. Selcuk Med J 2020;36(2): 123-128
Disclosure: None of the authors has a financial interest in any of the products, devices, or drugs mentioned in this article. The research was not sponsored by an outside organization. All authors have agreed to allow full access to the primary data and to allow the journal to review the data if requested. 
reported in multiple randomized controlled trials (57). Furthermore, DOACs have become the preferred treatment in patients with non-valvular AF due to their favorable risk-benefit profile compared to warfarin, exemplified by significantly reduced intracranial hemorrhage, stroke and mortality rates (8). Despite demonstrating critical advantages compared to warfarin, the bleeding side effects of DOACs can still be worrying, as is the case with all anticoagulants (9).

Since these drugs cannot be monitored, the probability of bleeding cannot be predetermined. Therefore, patient-specific determination of the type of DOAC and its dosage are of paramount importance to prevent adverse events and bleeding. In this context, platelet indices that are known to be related to tromboembolism and bleeding can be used in the selection of patient-specific DOACs. Determining and monitoring the parameters that predict bleeding and stroke (such as platelet indices) will provide critical data to the clinician and can facilitate correct treatment.

Platelet indices are comprised of the following parameters: platelet count, platelet distribution width (PDW), mean platelet volume (MPV), plateletcrit (PCT), and platelet larger cell ratio (P-LCR); these measurements can be routinely evaluated by a complete blood count (CBC). Previous studies have shown that platelet indices are associated with many ischemic, inflammatory and thrombotic events $(10,11)$. The relationships between platelet indices and hemorrhage was also investigated in several studies which showed that especially MPV and PDW were associated with bleeding tendency (12-14). Another important factor to consider in this topic is the fact that many drugs are known to affect platelet indices, while platelet indices can also alter the efficacy of drugs (15.16). Therefore, the relationships between platelet indices and bleeding may hold the key to correct DOAC selection, which would lead to more efficient anticoagulation management in patients with $\mathrm{AF}$.

To the best of our knowledge, there is no study investigating the relationship between DOACs and platelet indices in the literature. This study examined the effect of DOACs on platelet indices in patients with non-valvular AF with regard to bleeding and thromboembolic events.

\section{PATIENTS AND METHODS}

This study was designed as a retrospective cohort study. After reviewing our hospital records, patients with non-valvular AF and a CHADSVASc score of 1 or greater that used dabigatran, rivaroxaban, or apixaban between January 2008 and August 2018 were evaluated for inclusion into the study. Those with accessible $\mathrm{CBC}$ results before the start of DOAC treatment and after 6-7 months of usage were included the study. Patients whose $\mathrm{CBC}$ records could not be accessed and those who were on any type of antiaggregant (antiplatelet) or anticoagulant treatment apart of DOACs were excluded from the study. Patients that had been prescribed edoxaban were not included in the study as there were only a few patients on this drug because edoxaban has only recently received approval for use in Turkey. Patients were grouped according to type of DOAC used (dabigatran $150 \mathrm{mg}$ twice daily, rivaroxaban 20 once daily and apixaban $5 \mathrm{mg}$ twice daily) and these groups were studied by division into two separate subgroups comprised of patients with bleeding and no bleeding. The presence of bleeding was defined as having minor or major bleeding events during the course of treatment with DOACs. Major bleeding was defined as hemorrhage requiring blood transfusion and/or hospital admission. Minor bleeding was defined as self-limiting hemorrhages and bleeding events that did not fit the major bleeding definition.

The social security institution in our country requires the demonstration of warfarin ineffectiveness in order to provide coverage for DOACs in patients with AF. Therefore, all patients in the study group had been started on DOACs after using warfarin to no effect without an INR on therapeutic range. Adverse events such as bleeding and stroke in the patients were examined through medical records and recorded. In addition, patients were contacted by telephone to assess if they had received treatment at another hospital and to determine whether they had bleeding, transient ischemic attack or stroke as long as they were using DOACs. Patients who could not be reached by phone were excluded from the study. Blood samples were obtained by venous puncture in tubes containing ethylene diamine tetraacetic acid anticoagulant (EDTA). We used a blood cell counter (Sysmex XN-1000 ${ }^{\mathrm{TM}}$ Hematology Analyzer) to analyze the platelet indices in complete blood.

The CHADSVASc and HASBLED scores were calculated by cardiologists involved in the study according to data obtained from our hospital database. Patients' platelet counts, MPV, PDW, P-LCR, PCT values and demographic information were also obtained from the hospital archive and were used for the study. This study was approved by the Ethics 
Table 1. According to the anticoagulant drug used in the study group, demographic and clinical features

\begin{tabular}{|c|c|c|c|c|}
\hline & Dabigatran (n 107) & Rivoraxaban (n 114) & Apiksaban (93) & $P$ value \\
\hline$\overline{A g e}($ mean $\pm S D)$ & $71 \pm 9$ & $73 \pm 9$ & $71 \pm 8$ & $p=0.292$ \\
\hline \multicolumn{5}{|l|}{ Sex } \\
\hline Male & 39 & 40 & 25 & $p=0.306$ \\
\hline Female & 68 & 74 & 68 & \\
\hline HT & 81 & 84 & 70 & $p=0.936$ \\
\hline DM & 25 & 26 & 19 & $\mathrm{P}=0.872$ \\
\hline $\mathrm{CF}$ & 8 & 13 & 6 & $p=0.395$ \\
\hline CVD & 24 & 18 & 25 & $p=0.144$ \\
\hline CRF & 3 & 9 & 5 & $\mathrm{P}=0.216$ \\
\hline CLF & 1 & 1 & 0 & $p=0.654$ \\
\hline
\end{tabular}

Committee of the Eskisehir Osman Gazi University (Date: 26/09/2018 and No: 2018-213).

\section{Statistical Analysis}

Between group comparisons of the parameters were performed with the one-way ANOVA test as all variables were normally distributed. The paired samples t-test was used to determine differences between pre- and post-treatment results. Categorical variables were compared with chi-square tests. All analyses were performed with the SPSS version 20 computer software. Statistical significance was $\mathrm{p} \leq 0.05$.

\section{RESULTS}

A total of 301 patients were included in the study, $96(31.9 \%)$ were male. and ages ranged from 37 to 89 years with a mean $\pm S D$ value of $72 \pm 9$ years. Among these patients, $103(34.2 \%)$ were using dabigatran, $107(35.5 \%)$ were on rivaroxaban and 91 (30.2\%) were using apixaban (Table 1).

$\mathrm{T}$ here was no difference between groups in terms of baseline blood values except for P-LCR. The initial mean P-LCR value in the rivaroxaban group was significantly lower than those using dabigatran. In terms of final CBC results (6-7th month), no significant differences between groups were found ( $p>0.05)$. Baseline and final CBC results of the study group are depicted in Table 12. When time-bound differences were evaluated, P-LCR levels were found to reduce significantly among patients using dabigatran and apixaban (Table 2-3).

The CHADSVASc scores of the study group varied between 1-7 (mean \pm SD: $3 \pm 1$ ); the HASBLED scores ranged from 1-5 (mean $\pm S D$ : $3 \pm 1$ ). The distribution of CHADSVASc and HASBLED scores in regard to anticoagulant drugs are given in Table 34. Minor and/ or major bleeding developed in 32 patients (10.6\%) in the study group. The mean \pm SD HASBLED score was $2.67 \pm 0.67$ (min-max: 1-5) in patients with no bleeding and $3.03 \pm 0.78$ (min-max: $2-5$ ) in patients with bleeding, the difference was statistically significant $(p=0.005)$. Bleeding frequencies were not affected by type of medication and were similar in all groups ( $p>0.05$ ) (Table 4-5). There was also no significant

Table 2. According to the anticoagulant drug used in the study group, initial and final blood values

\begin{tabular}{|c|c|c|c|c|}
\hline & Dabigatran $(n=107)$ & Rivaroxaban $(n=114)$ & Apixaban $(n=93)$ & p value \\
\hline \multicolumn{5}{|c|}{ Initial Measures } \\
\hline PLT & $239.67 \pm 52.87$ & $238.39 \pm 61.73$ & $254.10 \pm 80.02$ & 0.183 \\
\hline PDW & $13.64 \pm 2.71$ & $13.03 \pm 3.87$ & $12.93 \pm 2.18$ & 0.203 \\
\hline MPV & $10.47 \pm 1.29$ & $10.40 \pm 1.42$ & $10.57 \pm 1.14$ & 0.661 \\
\hline PLCR & $31.11 \pm 6.92 a$ & $28.51 \pm 7.32 b$ & $30.18 \pm 7.80 a, b$ & 0.035 \\
\hline PCT & $0.25 \pm 0.06$ & $0.25 \pm 0.09$ & $0.27 \pm 0.08$ & 0.242 \\
\hline \multicolumn{5}{|c|}{ Final Measures } \\
\hline PLT & $234.81 \pm 54.56$ & $247.15 \pm 66.72$ & $249.64 \pm 94.52$ & 0.305 \\
\hline PDW & $13.03 \pm 4.67$ & $12.72 \pm 4.13$ & $12.26 \pm 3.65$ & 0.439 \\
\hline MPV & $10.70 \pm 1.42$ & $10.69 \pm 1.57$ & $10.70 \pm 1.86$ & 0.998 \\
\hline PLCR & $29.69 \pm 8.60$ & $28.66 \pm 8.26$ & $27.71 \pm 6.42$ & 0.218 \\
\hline PCT & $0.25 \pm 0.06$ & $0.26 \pm 0.07$ & $0.26 \pm 0.09$ & 0.799 \\
\hline
\end{tabular}

*Same latters denotes the lack of statistical significance 
Table 3. Change between initial and final blood values according to anticoagulant drugs

\begin{tabular}{|c|c|c|c|c|}
\hline & İnitial Mean $\pm S D$ & Final Mean $\pm S D$ & Mean Difference $\pm S E$ & $p$ \\
\hline \multicolumn{5}{|l|}{$\overline{\mathrm{PLT}}$} \\
\hline Dabigatran & $239.67 \pm 52.87$ & $234.81 \pm 54.56$ & $3.88 \pm 3.83$ & 0.218 \\
\hline Rivaroxaban & $238.39 \pm 61.73$ & $247.15 \pm 66.72$ & $-7.59 \pm 4.81$ & 0.084 \\
\hline Apixaban & $254.10 \pm 80.02$ & $249.64 \pm 94.52$ & $4.99 \pm 5.53$ & 0.431 \\
\hline \multicolumn{5}{|l|}{ PDW } \\
\hline Dabigatran & $13.64 \pm 2.71$ & $13.03 \pm 4.67$ & $0.61 \pm 0.43$ & 0.173 \\
\hline Rivaroxaban & $13.03 \pm 3.87$ & $12.72 \pm 4.13$ & $0.29 \pm 0.47$ & 0.534 \\
\hline Apixaban & $12.93 \pm 2.18$ & $12.26 \pm 3.65$ & $0.67 \pm 0.35$ & 0.063 \\
\hline \multicolumn{5}{|l|}{ MPV } \\
\hline Dabigatran & $10.47 \pm 1.29$ & $10.70 \pm 1.42$ & $-0.020 \pm 0.11$ & 0.500 \\
\hline Rivaroxaban & $10.40 \pm 1.42$ & $10.69 \pm 1.57$ & $-0.27 \pm 0.17$ & 0.121 \\
\hline Apixaban & $10.57 \pm 1.14$ & $10.70 \pm 1.86$ & $-0.013 \pm 0.019$ & 0.519 \\
\hline \multicolumn{5}{|l|}{ PLCR } \\
\hline Dabigatran & $31.11 \pm 6.92$ & $29.69 \pm 8.60$ & $1.26 \pm 0.56$ & 0.018 \\
\hline Rivaroxaban & $28.51 \pm 7.32$ & $28.66 \pm 8.26$ & $-0.23 \pm 0.74$ & 0.832 \\
\hline Apixaban & $30.18 \pm 7.80$ & $27.71 \pm 6.42$ & $2.47 \pm 0.60$ & 0.001 \\
\hline \multicolumn{5}{|l|}{ PCT } \\
\hline Dabigatran & $0.25 \pm 0.06$ & $0.25 \pm 0.06$ & $0.00 \pm 0.00$ & 0.941 \\
\hline Rivaroxaban & $0.25 \pm 0.09$ & $0.26 \pm 0.07$ & $-0.01 \pm 0.01$ & 0.370 \\
\hline Apixaban & $0.27 \pm 0.08$ & $0.26 \pm 0.09$ & $0.01 \pm 0.01$ & 0.105 \\
\hline
\end{tabular}

difference between initial platelet indices and final platelet indices (6-7th months) between patients with hemorrhage and those without hemorrhage ( $p$ $<0.005)$.

\section{DISCUSSION}

This study examined the effect of DOACs on platelet indices in patients with non-valvular AF, as well as the effect of platelet indices on DOAC efficacy and bleeding. However, apart from the reduction in P-LCR values in recipients of apixaban and dabigatran, no significant changes were observed. To the best of our knowledge, there is no previous study investigating the relationship between DOACs and platelet indexes. However, in some studies it has been observed that antiaggregant and anticoagulant drugs have effects on platelet indices (17). In a study by Arık et al., MPV, PDW, and PCT were higher in patients with non-valvular AF at baseline, while these values decreased after warfarin administration and were similar to those with sinus rhythm (18). The effect

Table 4. Distribution of chadsvasc and hasbled scores according to anticoagulant drug use in the study group

\begin{tabular}{llcc}
\hline Anticoagulant & \multicolumn{1}{c}{ Chadvasc } & Hasbled & p value \\
& & Mean \pm SD & \\
\hline Dabigatran & $3 \pm 1$ & $3 \pm 1$ & 0.752 \\
Rivaroxaban & $3 \pm 1$ & $3 \pm 1$ & \\
Apixaban & $3 \pm 1$ & $3 \pm 1$ & \\
\hline
\end{tabular}

of EDTA, an anticoagulant, on platelets is also known (19). In one study, the platelet reactivity of patients using rivoraxaban and dabigatran were examined and no significant difference was found between preand post-treatment (7th day after beginning DOAC therapy) results. (20). In the current study, it was concluded that DOACs (except for the reduction in P-LCR values with apixaban and dabigatran) do not affect platelet indices or platelet activity. Patients that had been prescribed edoxaban were not included in the study as there were only a few patients on this drug because edoxaban has only recently received approval for use in Turkey. The number of patients under low dose dabigatran and rivaroxaban were few and no patients were under low dose apixaban treatment. For this reason the comparison between low dose NOAC treatments cannot be done so these patients were excluded from the study.

It has been observed that the same drug has different effects on the platelet indices in different populations or different patient groups. For example,

Table 5. Bleeding rates according to the anticoagulant used in the study group

\begin{tabular}{llll}
\hline & $\begin{array}{l}\text { No bleeding } \\
\mathbf{n}(\%)\end{array}$ & $\begin{array}{l}\text { Bleeding } \\
\mathbf{n}(\%)\end{array}$ & $\mathbf{p}$ \\
\hline Dabigatran & $92(89.3)$ & $11(10.7)$ & 0.955 \\
Rivaroxaban & $95(88.8)$ & $12(11.2)$ & \\
Apixaban & $82(90.1)$ & $9(9.9)$ & \\
\hline
\end{tabular}


when aspirin was given during an acute myocardial infarction, it was observed to affect MPV (21), while a study on patients with paroxysmal atrial fibrillation found that aspirin had no effect on MPV (22). This can be the result of inflammation or disease-specific treatment of different illnesses. It is known that many variables affect platelet indices, such as body mass index, smoking, cholesterol, glucose, triglycerides, systolic or diastolic blood pressure and antiplatelet drug use (23). Because of these differences, conflicting results have been obtained and reported in a number of studies. In our study, we tried to eliminate these differences by measurement of platelet indices in a patient population in which the only variable that changed between the first and final measurements was DOAC treatment.

There was no difference in bleeding events among our groups. Major bleeding (gastrointestinal bleeding) occurred twice in each group, while minor bleeding events were also similar. When studies by Rely, Aristotle and Rocetaf were examined, hemorrhage risk was reported to be decreased with dabigatran (110 mg twice daily) and apixaban (twice daily) when compared with warfarin. Whereas dabigatran $(150 \mathrm{mg}$ twice daily) and rivaroxaban (20 or $15 \mathrm{mg}$, once daily) were both found to have similar risk for hemorrhage compared to warfarin. The risk of major GIB was similar with dabigatran (110 mg twice daily) and apixaban (twice daily) versus warfarin, while risk was increased with dabigatran (150 mg twice daily) and rivaroxaban (20 or $15 \mathrm{mg}$, once daily). Intracranial bleeding risk was decreased with all DOACs versus warfarin. In our study, there was no significant difference in platelet indexes such as MPV, PDW, platelet count in all three DOACs groups, which may have caused the lack of difference in the number of bleeding events. However, this finding should be elucidated by larger studies.

Some studies showed that decrease in platelet indices is associated with increased bleeding events (12-14). Contrary to these studies, P-LCR, which is also a platelet index, was not associated with haemorrhage or thrombosis according to our study. This may be due to the fact that other platelet indices were not affected. In addition apixaban and dabigatran treatment affect the P-LCR which may show that DOACs has an effect on platelet index.

The relationship of platelet indices with transischemic attack and stroke has been investigated in several studies $(20,24)$. In our study, only one patient was hospitalized with a stroke. Therefore, the relationships between platelet indices and stroke could not be examined.

Our study has some limitations. Firstly, this is a retrospective study and shares the limitations of all retrospective studies. Secondly, blood samples must be studied within one hour to accurately measure the MPV value (12). Although CBC samples are routinely studied within one hour at our hospital, there was no way to evaluate whether this was true for all samples because the study was performed retrospectively. Finally, parameters affecting platelet indices such as smoking, alcohol use, and body mass index of patients were not assessed.

Although our study concludes that DOACs only have minor effects on platelet indices, this result may be due to the fact that the study population was single-centered, or that the number of patients were low. We believe determining predictive parameters for correct treatment and the reduction of side effects for non-valvular AF patients using oral anticoagulants are worth investigating, as these drugs have critical effects on the risks for bleeding and stroke. We therefore believe that this study could provide insight into the evaluation of platelet indices in patients with non-valvular AF. Further studies with larger patient groups must be performed in order to increase our understanding of the relationships between platelet indices and the clinical results/side effects of DOACs.

\section{CONCLUSION}

This study showed that apixaban, rivoraxaban and dabigatran had no effect on platelet count, MPV, PDW and PCT values in patients with nonvalvular AF. Apixaban and dabigatran were found to significantly reduce P-LCR after 6 months of use, while rivaroxaban had no effect. There was also no significant difference between drugs in terms of the number of bleeding events in the current study.

Conflict of interest: Authors declare that there is no conflict of interest between the authors of the article.

Financial conflict of interest: Authors declare that they did not receive any financial support in this study.

Address correspondence to: Fatih Aydin, Eskişehir City Hospital, Department of Cardiology, 26080, 71 Evler Mahallesi Eskişehir, Turkey

Telephone: +905337226874

e-mail:drfatihaydin@hotmail.com

\section{REFERENCES}

1. Camm AJ, Kirchhof P, Lip GY, et al. The european heart 
rhythm association, and the european association for cardio-thoracic surgery. Guidelines for the management of atrial fibrillation: The task force for the management of atrial fibrillation of the european society of cardiology (ESC). Eur Heart J 2010;31:2369-429.

2. Hylek EM, Go AS, Chang Y, et al. Effect of intensity of oral anticoagulation on stroke severity and mortality in atrial fi brillation. N Engl J Med 2003;349:1019-26.

3. Hart RG, Pearce LA. Aguilar MI. Meta-analysis: Antithrombotic therapy to prevent stroke in patients who have nonvalvular atrial fibrillation. Ann Intern Med 2007;146:857-67.

4. Ruff CT, Giugliano RP, Braunwald E, et al. Comparison of the efficacy and safety of new oral anticoagulants with warfarin in patients with atrial fibrillation: A meta-analysis of randomised trials. Lancet 2014;383:955-62.

5. Connolly SJ, Ezekowitz MD, Yusuf S, et al. Steering committee and investigators. Dabigatran versus warfarin in patients with atrial fibrillation. N Engl J Med 2009;361:113951.

6. Granger CB, Alexander JH, McMurray JJ, et al. Aristotle committees and investigators. Apixaban versus warfarin in patients with Atrial fibrillation. N Engl J Med 2011;365:98192.

7. Patel MR, Mahaffrey KW, Garg J, et al. Rocket af investigators. Rivaroxaban versus warfarin in nonvalvular atrial fibrillation. N Engl J Med 2011;365:883-91.

8. Ruff CT, Giugliano RP, Braunwald E, et al. Comparison of the efficacy and safety of new oral anticoagulants with warfarin in patients with atrial fibrillation: A meta-analysis of randomized trials. Lancet 2014;383955-62.

9. Eikelboom J, Merli G. Bleeding with direct oral anticoagulants vs warfarin: Clinical experience, Am J Med 2016;129:33-40.

10. Ates I, Bulut M, Ozkayar N, et al. Association between high platelet indices and proteinuria in patients with hypertension. Ann Lab Med 2015;35:630-4.

11. Ates $\mathrm{H}$, Ates I, Kundi $\mathrm{H}$, et al. Diagnostic validity of hematologic parameters in evaluation of massive pulmonary embolism. $J$ Clin Lab Anal 2017;31(5).

12. Senel T, Ates I, Demir BF, et al. The diagnostic valueof platelet indices in the gastrointestinal system bleeding and its place in predicting prognosis. Am J Emerg Med 2018;3.

13. Tanoglu A, Kara M, Yazgan Y, et al. Artmış ortalama trombosit hacmi üst gastrointestinal sistem kanamalarında yatış süresi ve transfüzyon ihtiyacı ile ilişkilidir. Gulhane Medical Journal $2015 ; 57$.
14. Decousus H, Tapson VF, Bergmann JF, et al. Factors at admission associated with bleeding risk in medical patients: findings from the improve investigators. Chest 2011;139:6979.

15. Baigent C, Sudlow C, Collins R, et al. Collaborative metaanalysis of randomised of antiplatelet therapy for prevention of death, myocardial infarction, and stroke in high risk patients. BMJ 2002;324:71-86.

16. Gasparyan AY, Watson T, Lip GY. The role of aspirin in cardiovascular prevention: Implications of aspirin resistance. J Am Coll Cardiol 2008;51:1829-43.

17. American diabetes association. Classification and diagnosis of diabetes. Diabetes Care 2015;38:8-16.

18. Arık OZ, Özkan B, Kutlu R, et al. Relationship between platelet indices and international normalized ratio in patients with non-valvular atrial fibrillation, Platelets 25:5,311-6.

19. Dastjerdi MS, Emami T, Najafian A, et al. Mean platelet volume measurement, Edta or citrate? Hematology 2006;11:317-9.

20. Farah R, Samra N. Mean platelets volume and neutrophil to lymphocyte ratio as predictors of stroke. J Clin Lab Anal 2018;32(1).

21. Huczek Z, Filipiak KJ, Kochman J, et al. Baseline platelet size is increased in patients with acute coronary syndromes developing early stent thrombosis and predicts future residual platelet reactivity. A case-control study. Thromb Res 2010;125:406-12.

22. Colkesen $\mathrm{Y}$, Coskun I, Muderrisoglu H. The effect of aspirin on mean platelet volume in patients with paroxysmal atrial fibrillation. Platelets 2013;24:263-6.

23. Castelnuovo A, Curtis A, Spinelli M, et al. White blood cell count, sex and age are major determinants of heterogeneity of platelet indices in an adult general population: Results from the Moli-Sani project lolanda santimone. Haematologica 2011; 96:1180-8.

24. Zhang J, Zhang J, Sun H. Association between platelet function and recurrent ischemic vascular events after Tia and minor stroke. CP 2017;55:789-97. 